\title{
A Subpressor Dose of Angiotensin II Elevates Blood Pressure in a Normotensive Rat Model by Oxidative Stress
}

\author{
M. M. GOVENDER ${ }^{1}$, A. NADAR ${ }^{2}$ \\ ${ }^{1}$ Department of Physiology, School of Pathology and Preclinical Sciences, Faculty of Health \\ Sciences, Sefako Makgatho Health Sciences University, Pretoria, South Africa, ${ }^{2}$ Discipline \\ of Physiology, School of Basic and Applied Medical Sciences, Faculty of Health Sciences, \\ University of Kwa-Zulu Natal, Durban, South Africa
}

Received January 16, 2014

Accepted August 8, 2014

On-line October 15, 2014

\section{Summary}

Oxidative stress is an imbalance between free radicals and antioxidants, and is an important etiological factor in the development of hypertension. Recent experimental evidence suggests that subpressor doses of angiotensin II elevate oxidative stress and blood pressure. We aimed to investigate the oxidative stress related mechanism by which a subpressor dose of angiotensin II induces hypertension in a normotensive rat model. Normotensive male Wistar rats were infused with a subpressor dose of angiotensin II for 28 days. The control group was sham operated and infused with saline only. Plasma angiotensin II and $\mathrm{H}_{2} \mathrm{O}_{2}$ levels, whole-blood glutathione peroxidase, and AT-1a, Cu/Zn SOD, and p22phox mRNA expression in the aorta was assessed. Systolic and diastolic blood pressures were elevated in the experimental group. There was no change in angiotensin II levels, but a significant increase in AT1a mRNA expression was found in the experimental group. mRNA expression of p22phox was increased significantly and $\mathrm{Cu} / \mathrm{Zn}$ SOD decreased significantly in the experimental group. There was no significant change to the $\mathrm{H}_{2} \mathrm{O}_{2}$ and $\mathrm{GPx}$ levels. Angiotensin II manipulates the free radical-antioxidant balance in the vasculature by selectively increasing $\mathrm{O}_{2}{ }^{-}$production and decreasing SOD activity and causes an oxidative stress induced elevation in blood pressure in the Wistar rat.

\section{Key words}

Angiotensin II • Oxidative stress • Subpressor • Superoxide radical $\bullet$ Hypertension

\section{Corresponding author}

M. M. Govender, Sefako Makgatho Health Sciences University, 3111 Setlogelo Street, Ga-Rankuwa, Pretoria, Gauteng, P. O. Box 130, Medunsa, Pretoria, 0204, South Africa. Fax: +2712 521 5823. E-mail: Melvin.govender@smu.ac.za

\section{Introduction}

Oxidative stress describes a state of potential damage caused by free radicals to biologically critical molecules, and has been linked with various disease states including hypertension (Sies 1997, Halliwell and Gutteridge 1999, Dalle-Donne et al. 2006, Harrison et al. 2007). The elevation of the reactive oxygen species (ROS) superoxide $\left(\mathrm{O}_{2}{ }^{-}\right)$and hydrogen peroxide $\left(\mathrm{H}_{2} \mathrm{O}_{2}\right)$ disturbs the prooxidant-antioxidant balance and has been shown to be the major contributors to the pathophysiology of hypertension (Paravicini and Touyz 2008). The $\mathrm{O}_{2}{ }^{-}$radical has been shown to scavenge nitric oxide and reduce its bioavailability, thus reducing its vasodilatory role on the vasculature (McIntyre et al. 1999, Bryan 2006). The relative increase of both $\mathrm{O}_{2}{ }^{-}$and $\mathrm{H}_{2} \mathrm{O}_{2}$ with resultant tissue oxidative stress has also been shown to decrease the natriuretic and diuretic properties of the kidney, thus reducing the organs ability to regulate blood pressure (Meng et al. 2003). Both these species have also been shown to promote vascular smooth muscle cell (VSMC) growth, and contribute to the blood pressure amplifier consequence of vascular remodeling (Touyz 2003, 2004, Taniyama and Griendling 2003, Paravicini

PHYSIOLOGICAL RESEARCH • ISSN 0862-8408 (print) • ISSN 1802-9973 (online) 
and Touyz 2008).

The octapeptide angiotensin II (Ang II) plays an important physiological role in blood pressure regulation. Ang II acts to elevate blood pressure by its well established pressor effects, which broadly increase plasma volume and vascular resistance (Sealey and Laragh 1995). Compelling experimental evidence suggests that both the Ang II and the oxidative stress mechanisms are linked, where Ang II has been shown to stimulate the production of $\mathrm{O}_{2}^{-}$in the vasculature of rats, via the activation of the membrane bound enzyme NADPH oxidase (Griendling et al. 1994, Rajagopalan et al. 1996, Fukai et al. 1999, Zalba et al. 2000). NADPH oxidase is a multi-subunit enzyme that catalyses $\mathrm{O}_{2}{ }^{-}$ production via the 1-electron reduction of $\mathrm{O}_{2}$ using NADPH/NADH (Paravicini and Touyz 2008). The Ang II and oxidative stress relationship and its link to an elevated blood pressure in hypertension is outlined in the proposed scheme in Figure 1.

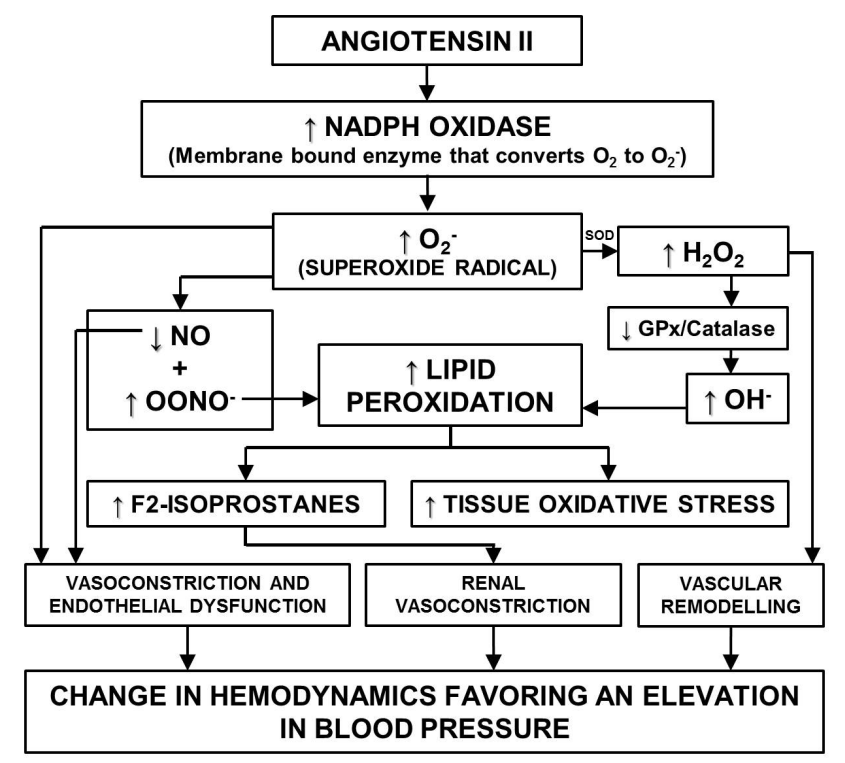

Fig. 1. Role of angiotensin II derived oxidative stress in blood pressure elevation.

Previous studies have shown that infusion of subpressor doses of Ang II over different time frames in normotensive animal models induces hypertension and elevates markers of oxidative stress (Haas et al. 1999, Reckelhoff et al. 2000). Thus this study was undertaken to investigate the mechanism by which a chronic subpressor dose of Ang II induces hypertension in a normotensive rat model and determine the role of oxidative stress in the vascular compartment on the elevation of blood pressure.

\section{Methods}

\section{Animal protocol}

Experimental animals were obtained from the University of Kwa-Zulu Natal Biomedical Resource Unit. The University of Kwa-Zulu Natal Animal Ethics Subcommittee approved all animal experiments for this study.

\section{Drug administration}

Sixteen male Wistar rats $(150 \mathrm{~g})$ were randomly divided into 2 groups $(\mathrm{n}=8)$ viz. the Control group (Wistar-Saline infused) and the Experimental group (Wistar-Ang II infused). The animals were anesthetized using a combination of ketamine $(80 \mathrm{mg} / \mathrm{kg})$ and xylazine $(10 \mathrm{mg} / \mathrm{kg})$ and further subjected to an inhalant gaseous anesthesia (0.5-2\% halothane) to maintain anesthesia. Using sterile techniques, an incision was made in the midscapular region, where a pocket was created with a hemostat and the osmotic mini-pumps (ALZET ${ }^{\mathrm{TM}}$ model 2004; Alza Corp) containing Ang II (Sigma A9525) dissolved in $0.9 \%$ saline (infusion rate $10 \mathrm{ng} / \mathrm{kg} / \mathrm{min}^{-1}$ ) (Reckelhoff et al. 2000) were implanted and the pocket subsequently sutured. These osmotic pumps are designed to deliver the predetermined dose for a period of 28 days. The control group was sham operated, and underwent the same surgical procedure, however their mini osmotic pumps contained $0.9 \%$ saline only.

\section{Blood pressure measurements}

Systolic blood pressure (SBP) and diastolic blood pressure (DBP) was measured weekly using the non-invasive tail cuff method as previously described by Somova et al. (1998) (II TC Model 31 NIBP). Animals were trained and acclimatized to the blood pressure measuring equipment for a period of 1 week prior to the commencement of the experimentation.

\section{Termination}

After 28 days all groups were sacrificed by exsanguination. Briefly, animals were first sedated by placing them in a gas chamber containing $5 \%$ halothane. Whole blood was collected by cardiac puncture in EDTA coated test tubes. Plasma was processed, aliquoted and snap frozen (in liquid nitrogen) for analysis. Ascending aorta segments were also collected for mRNA analysis and also snap frozen. All collected tissue was stored at $-70{ }^{\circ} \mathrm{C}$ for further analyses. 


\section{RNA extraction and cDNA synthesis}

Total RNA was extracted from the ascending aorta segments using a modified Trizol (Invitrogen) protocol (Perou et al. 1999). RNA pellets were dissolved in diethylpyrocarbonate-treated water and the concentration was determined spectrophotometrically at $260 \mathrm{~nm}$. cDNA synthesis was performed on $4 \mathrm{ng}$ total RNA, using the BioRad iScript cDNA synthesis kit according to the manufacturer's protocol (Bio-Rad, Hercules, CA, USA).

Real-time polymerase chain reaction (PCR) protocol for AT1-a, p22phox, Cu/Zn SOD and GAPDH

Each real-time PCR reaction was performed in a total volume of $10 \mu \mathrm{l}$ LightCycler mastermix. Mastermix was made up of $4.8 \mu \mathrm{l}$ water, $1.2 \mu \mathrm{lgCl}_{2}(3 \mathrm{mmol} / \mu \mathrm{l})$, $0.5 \mu \mathrm{l}$ reverse primer, $0.5 \mu \mathrm{l}$ of forward primer, $1 \mu \mathrm{l}$ Fast Start SYBR Green I and $2 \mu$ sample cDNA for AT1-a;

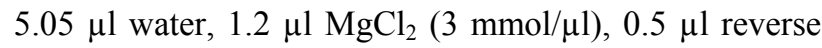
primer, $0.25 \mu \mathrm{l}$ of forward primer, $1 \mu \mathrm{l}$ Fast Start SYBR Green I and $2 \mu \mathrm{l}$ sample cDNA for p22phox; $4.8 \mu \mathrm{l}$ water, $1.2 \mu \mathrm{lgCl}_{2}(3 \mathrm{mmol} / \mu \mathrm{l}), 0.5 \mu \mathrm{l}$ reverse primer, $0.5 \mu \mathrm{l}$ of forward primer, $1 \mu$ l Fast Start SYBR Green I and $2 \mu 1$ sample cDNA for $\mathrm{Cu} / \mathrm{Zn}$ SOD and $4.8 \mu \mathrm{l}$ water, $1.2 \mu 1 \mathrm{MgCl}_{2}(3 \mathrm{mmol} / \mu \mathrm{l}), 0.5 \mu \mathrm{l}$ reverse primer, $0.5 \mu \mathrm{l}$ of forward primer, $1 \mu \mathrm{l}$ Fast Start SYBR Green I and $2 \mu \mathrm{l}$ sample cDNA for GAPDH. Respective primer sequences are listed in Table 1.

Table 1. Primer sequences used in real-time PCR assay.

\begin{tabular}{ll}
\hline mRNA & Oligonucleotides sequence \\
\hline $\begin{array}{l}\text { p22phox } \\
\text { (forward) } \\
\text { p22phox } \\
\text { (reverse) }\end{array}$ & 5'-GCTCATCTGTCTGCTGGAGTA-3' \\
$\begin{array}{l}\text { Cu/Zn SOD } \\
\text { (forward) }\end{array}$ & 5'-CGGATGAAGAGAGGCATGTTG-3' \\
$\begin{array}{l}\text { Cu/Zn SOD } \\
\text { (reverse) } \\
\text { ATla } \\
\text { (forward) } \\
\text { ATla } \\
\text { (reverse) }\end{array}$ & 5'-TTGGCCACACCGTCCTTT-3' \\
$\begin{array}{l}\text { GAPDH } \\
\text { (forward) }\end{array}$ & 5'-TTGGCCATGAAGAGAGGCATGTTG-3' \\
$\begin{array}{l}\text { GAPDH } \\
\text { (reverse) }\end{array}$ & 5'-CATGTCAGATCCACCACGGA-3' \\
\hline
\end{tabular}

Information derived from Moritz et al. (2003) for p22phox, Cu/Zn SOD and GAPDH, and Naito et al. (2002) for AT1a
All reactions were run in a Roche Lightcycler Ver. 1.5 with 1 cycle of $95^{\circ} \mathrm{C}(10 \mathrm{~min})$, followed by 45 cycles of $95^{\circ} \mathrm{C}(6 \mathrm{~s}), 65^{\circ} \mathrm{C}\left(6\right.$ seconds) and $72{ }^{\circ} \mathrm{C}$ (6 s) for AT-1a; 1 cycle of $95{ }^{\circ} \mathrm{C}(10 \mathrm{~min})$, followed by 45 cycles of $95^{\circ} \mathrm{C}(6 \mathrm{~s}), 58^{\circ} \mathrm{C}(10 \mathrm{~s})$ and $72{ }^{\circ} \mathrm{C}(6 \mathrm{~s})$ for p22phox; 1 cycle of $95^{\circ} \mathrm{C}(10 \mathrm{~min})$, followed by 40 cycles of $95^{\circ} \mathrm{C}(6 \mathrm{~s}), 58^{\circ} \mathrm{C}(10 \mathrm{~s})$ and $72{ }^{\circ} \mathrm{C}(6 \mathrm{~s})$ for $\mathrm{Cu} / \mathrm{Zn} \mathrm{SOD}$ and 1 cycle of $95^{\circ} \mathrm{C}(10 \mathrm{~min})$, followed by 45 cycles of $95^{\circ} \mathrm{C}(6 \mathrm{~s}), 65^{\circ} \mathrm{C}(6 \mathrm{~s})$ and $72{ }^{\circ} \mathrm{C}(6 \mathrm{~s})$ for GAPDH.

Each sample was run in duplicate. Relative mRNA copy numbers were calculated by generating standard curves using serial dilutions of a known concentration of cDNA. AT1-a, p22phox, Cu/Zn SOD and GAPDH mRNA levels were calculated as number of molecules per $\mu \mathrm{g}$ of cDNA.

Gene expression data for each of the groups mRNA was normalized with GAPDH, by expressing data as a ratio of each of AT1-a, p22phox and $\mathrm{Cu} / \mathrm{Zn}$ SOD respectively to GAPDH mRNA expression.

\section{Standard curve}

A dilution series of p22phox, $\mathrm{Cu} / \mathrm{Zn}$ SOD and AT1a and GAPDH amplicon were used as a standard template for reactions ranging from 1011 to 1020 copies per PCR reaction. Quantitative analysis of the data was done employing LightCycler analysis software (Version 3.3).

\section{Blood and plasma analysis}

\section{Plasma angiotensin II}

An aliquot of plasma underwent solid phase extraction according to the manufacturer's instructions using a C-18 Sep Column (BACHEM). The eluted fraction was assayed using a competitive enzyme immunoassay kit obtained from BACHEM.

\section{Plasma hydrogen peroxide}

Plasma $\mathrm{H}_{2} \mathrm{O}_{2} \quad$ levels was quantified colorimetrically using a commercially available kit from Assay Designs - Stressgen. The principle is based on the reaction of xylenol orange in an acidic solution with sorbitol and ammonium iron sulphate together with $\mathrm{H}_{2} \mathrm{O}_{2}$ to produce a purple color that is proportional to the $\mathrm{H}_{2} \mathrm{O}_{2}$ concentration in the sample.

\section{Blood glutathione peroxidase}

Glutathione Peroxidase (GPx) was quantified in whole blood using a commercially available kit from 
Randox Chemicals (RANSEL). This method is based on that of Paglia and Valentine (1967).

\section{Statistical analysis}

Statistical analysis was performed using Graphpad Instat (Version 5.0) and are represented as Mean \pm SEM. All means of the control and the experimental groups were compared with a Student's ttest and a $p<0.05$ was considered statistically significant.

\section{Results}

\section{Blood pressure}

Both SBP and DBP showed slow increases over the successive weeks in the experimental group, whereas the control group showed no significant change in SBP and DBP. Both the SBP and DBP was significantly higher $(20 \%)$ in the experimental group as compared to the control group at the end of the study at 28 days. Results are shown in Table 2.

Table 2. Weekly SBP and DBP.

\begin{tabular}{|c|c|c|c|c|}
\hline Group & Week 1 & Week 2 & Week 3 & Week 4 \\
\hline $\begin{array}{l}\text { Control } \\
(\mathrm{SBP}) \\
(\mathrm{mm} \mathrm{Hg})\end{array}$ & $116 \pm 2$ & $126 \pm 1$ & $123 \pm 1$ & $121 \pm 2$ \\
\hline $\begin{array}{l}\text { Experiment } \\
(\mathrm{SBP}) \\
(\mathrm{mm} \mathrm{Hg})\end{array}$ & $132 \pm 3^{*}$ & $134 \pm 4^{*}$ & $149 \pm 7^{*}$ & $152 \pm 6^{*}$ \\
\hline $\begin{array}{l}\text { Control } \\
(\mathrm{DBP}) \\
(\mathrm{mm} \mathrm{Hg})\end{array}$ & $80 \pm 1$ & $82 \pm 1$ & $83 \pm 1$ & $79 \pm 1$ \\
\hline $\begin{array}{l}\text { Experiment } \\
(\mathrm{DBP}) \\
(\mathrm{mm} \mathrm{Hg})\end{array}$ & $89 \pm 2^{*}$ & $89 \pm 4^{*}$ & $100 \pm 4^{*}$ & $99 \pm 4^{*}$ \\
\hline
\end{tabular}

* Statistically significant to control $-p<0.05$ )

\section{Plasma angiotensin II}

There was no significant change in the circulating plasma Ang II levels, results are shown in Table 3.

\section{Aorta AT-1a mRNA expression}

The experimental group had a significant $126 \%$ net increase in AT-1a mRNA expression as compared to the control group as shown in Table 3.
Aorta p22phox mRNA expression

The experimental group had a significant $154 \%$ net increase in p22phox mRNA expression as compared to the control group as shown in Table 3 .

Table 3. Experimental parameters.

\begin{tabular}{lcc}
\hline Parameter & Control & Experiment \\
\hline $\begin{array}{l}\text { Plasma angiotensin II } \\
\text { (pg/ml) }\end{array}$ & $1.13 \pm 0.28$ & $1.21 \pm 0.25$ \\
$\begin{array}{l}\text { Glutathione } \\
\text { peroxidase (units/ml) }\end{array}$ & $87553 \pm 3881$ & $81922 \pm 3163$ \\
$\begin{array}{l}\text { Hydrogen peroxide } \\
\text { (ng/ml) }\end{array}$ & $425.0 \pm 58.6$ & $499.0 \pm 49.6$ \\
AT-1a & $4.33 \pm 2.89$ & $9.77 \pm 0.52^{*}$ \\
p22phox & $5.75 \pm 0.13$ & $14.61 \pm 1.25^{*}$ \\
Cu/Zn SOD & $4.41 \pm 1.49$ & $0.83 \pm 0.25^{*}$ \\
\hline
\end{tabular}

* Statistically significant to control $-p<0.05$

Aorta $C u / Z n$ SOD mRNA expression

The experimental group had a significant $81 \%$ net decrease in $\mathrm{Cu} / \mathrm{Zn}$ SOD mRNA expression as compared to the control group as shown in Table 3.

\section{Glutathione peroxidase}

There was no significant change to the GPx levels in the blood as shown in Table 3.

\section{Hydrogen peroxide}

There was no significant change to the plasma $\mathrm{H}_{2} \mathrm{O}_{2}$ levels as shown in Table 3 .

\section{Discussion}

In this study we report that a subpressor dose of Ang II administered over a 28 day period in a normotensive rat model induces a significant elevation in blood pressure, from the start of the study to the end of the study at day 28. The elevation in blood pressure appears to be linked with the concomitant increase in oxidative stress in the vascular compartment that the Ang II infusion produces.

This study has shown that a subpressor dose of Ang II significantly increases p22phox mRNA expression in the vasculature. A previous study by Fukui et al. (1997) showed that an increase in p22phox mRNA expression translates to an increase in NADPH oxidase 
activity. The increase in NADPH oxidase activity would result in a concomitant increase in $\mathrm{O}_{2}{ }^{-}$production as shown in a well-controlled study by Zalba et al. (2000). We thus propose that the consequent increase in $\mathrm{O}_{2}^{-}$is responsible for the following blood pressure elevating mechanisms. Firstly $\mathrm{O}_{2}^{-}$is known to scavenge nitric oxide, thereby reducing its bioavailability, and thus decreasing its vasodilatory capacity and secondly $\mathrm{O}_{2}^{-}$is known to be a direct vasoconstrictor (de Champlain et al. 2004, Bryan 2006). Thus these two oxidative stress related mechanisms would act independently to increase total peripheral resistance and ultimately blood pressure as shown in the proposed scheme in Figure 1.

The decrease in $\mathrm{Cu} / \mathrm{Zn}$ SOD levels during Ang II infusion would blunt the neutralization of the superoxide radical in the vasculature. This action coupled with the increased NADPH oxidase activity would result in oxidative stress due to $\mathrm{O}_{2}^{-}$accumulation and its associated blood pressure elevating consequences as outlined in Figure 1.

The subpressor dose of Ang II resulted in no change to the circulating plasma Ang II levels, however it did increase the expression of the AT-1a receptor in the vasculature. It is suspected that the infusion of the subpressor dose of Ang II acts on renin release due to the elevation in blood pressure, in a classic negative feedback, to decrease circulating Ang II levels. This appears to be an attempt to thwart an increase in blood pressure by the pressor effects of Ang II. However the Ang II infusion appears to stimulate AT-1a and NADPH oxidase activity and thus potentiate only this specific modality of Ang II. The AT-1a receptor is widely distributed in various tissues including the vasculature, adrenal glands, kidneys, heart, lung, liver, testis, pituitary gland and brain and is known to mediate the blood pressure elevating properties of Ang II. In the vasculature it modulates vasoconstriction and the activity of NADPH oxidase (de Champlain et al. 2004). Thus the subpressor dose appears to stimulate NADPH oxidase activity via the AT-1a receptor and this result is fortified by a previous study that has shown that the administration of Ang II receptor blockers decreased NADPH oxidase activity in the vasculature and thus decreased $\mathrm{O}_{2}{ }^{-}$ production by the vasculature (de Champlain et al. 2004).
Our results show that the activity of NADPH oxidase is directly proportional to the activity of the AT-1a receptor where the infusion increased AT-1a by $126 \%$ and NADPH oxidase by $154 \%$. This is of clinical significance as Ang II receptor blockers would thus also be able to attenuate the deleterious effects of oxidative stress due to $\mathrm{O}_{2}{ }^{-}$accumulation and its associated blood pressure elevating actions, as well as its blockage of the normal pressor effects of Ang II.

We speculate that the $\mathrm{O}_{2}{ }^{-}$radical appears to be the exclusively implicated free radical species with regards to the elevation in blood pressure, as there was no change in $\mathrm{H}_{2} \mathrm{O}_{2}$ levels. This therefore shows that the subpressor dose of Ang II does not cause $\mathrm{H}_{2} \mathrm{O}_{2}$ accumulation. This is confirmed by the unchanged GPx levels which are usually elevated in response to elevated $\mathrm{H}_{2} \mathrm{O}_{2}$ levels (Jones 2002). The 'normal' $\mathrm{H}_{2} \mathrm{O}_{2}$ levels could also be due to the decreased SOD, which appears to result in a decreased dismutation of $\mathrm{O}_{2}{ }^{-}$to $\mathrm{H}_{2} \mathrm{O}_{2}$. This therefore eliminates $\mathrm{H}_{2} \mathrm{O}_{2}$ as the causative free radical species in the elevation of blood pressure. It should also be noted that the blood pressure elevating effects of $\mathrm{H}_{2} \mathrm{O}_{2}$ accumulation and dysregulation appear to be associated with progressive long-term derangements, i.e. vascular remodeling and oxidative stress related tissue damage (Hyoudou et al. 2006, Nishikawa et al. 2009). Thus it appears that a short-term elevation of blood pressure by the subpressor dose of Ang II is due exclusively to $\mathrm{O}_{2}{ }^{-}$ accumulation in the vascular compartment.

Therefore our results indicate that the subpressor dose of Ang II induces oxidative stress in the vascular compartment due to $\mathrm{O}_{2}{ }^{-}$accumulation by specifically increasing $\mathrm{O}_{2}^{-}$and suppressing SOD.

\section{Conflict of Interest}

There is no conflict of interest.

\section{Acknowledgements}

This work was supported by a grant from the National Research Foundation (NRF) of South Africa. The following groups and individuals are acknowledged for their technical assistance during the study: The Biomedical Resource Unit of the University of Kwa-Zulu Natal, Mr. R. Singh and Mr. S. Rhambarose.

\section{References}

BRYAN NS: Nitrite in nitric oxide biology: Cause or consequence? A systems-based review. Free Radic Biol Med 41: 691-701, 2006. 
DALLE-DONNE I, ROSSI R, COLOMBO R, GIUSTARINI D, MILZANI A: Biomarkers of oxidative damage in human disease. Clin Chem 52: 601-623, 2006.

DE CHAMPLAIN J, WU R, GIROUARD H, KARAS M, EL MIDAOUI A, LAPLANTE MA, WU L: Oxidative stress in hypertension. Clin Exp Hypertens 26: 593-601, 2004.

FUKAI T, SIEGFRIED MR, USHIO-FUKAI M, GRIENDLING KK, HARRISON DG: Modulation of extracellular superoxide dismutase expression by angiotensin II and hypertension. Circ Res 85: 23-28, 1999.

FUKUI T, ISHIZAKA N, RAJAGOPALAN S, LAURSEN JB, CAPERS Q, TAYLOR WR, HARRISON DG, DE LEON H, WILCOX JN, GRIENDLING KK: p22phox mRNA expression and NADPH oxidase activity are increased in aortas from hypertensive rats. Circ Res 80: 45-51, 1997.

GRIENDLING KK, MINIERI CA, OLLERENSHAW JD, ALEXANDER RW: Angiotensin II stimulates NADH and NADPH oxidase activity in cultured vascular smooth muscle cells. Circ Res 74: 1141-1148, 1994.

HAAS JA, KRIER JD, BOLTERMAN RJ, JUNCOS LA, ROMERO JC: Low-dose angiotensin II increases free isoprostane levels in plasma. Hypertension 34: 983-986, 1999.

HALLIWELL B, GUTTERIDGE JC: Free Radicals in Biology and Medicine, 3rd edition. Oxford University Press, Oxford, UK, 1999.

HARRISON DG, GONGORA MC, GUZIK TJ, WIDDER J: Oxidative stress and hypertension. J Am Soc Hypertens 1: 30-44, 2007.

HYOUDOU K, NISHIKAWA M, KOBAYASHI Y, UMEYAMA Y, YAMASHITA F, HASHIDA M: PEGylated catalase prevents metastatic tumor growth aggravated by tumor removal. Free Radic Biol Med 41: 1449-1458, 2006.

JONES DP: Redox potential of GSH/GSSG couple: assay and biological significance. Methods Enzymol 348: 98-112, 2002.

MCINTYRE M, BOHR DF, DOMINICZAK AF: Endothelial function in hypertension: the role of superoxide anion. Hypertension 34: 539-545, 1999.

MENG S, CASON GW, GANNON AW, RACUSEN LC, MANNING RD Jr: Oxidative stress in Dahl salt-sensitive hypertension. Hypertension 41: 1346-1352, 2003.

MORITZ F, MONTEIL C, ISABELLE M, BAUER F, RENET S, MULDER P, RICHARD V, THUILLEZ C: Role of reactive oxygen species in cocaine-induced cardiac dysfunction. Cardiovasc Res 59: 834-843, 2003.

NAITO Y, TSUJINO T, FUJIOKA Y, OHYANAGI M, IWASAKI T: Augmented diurnal variations of cardiac reninangiotensin system in hypertensive rats. Hypertension 40: 827-833, 2002.

NISHIKAWA M, HASHIDA M, TAKAKURA Y: Catalase delivery for inhibiting ROS-mediated tissue injury and tumor metastasis. Adv Drug Delivery Rev 61: 319-326, 2009.

PAGLIA DE, VALENTINE WN: Studies on the quantitative and qualitative characterization of erythrocyte glutathione peroxidase. J Lab Clin Med 70: 158-169, 1967.

PARAVICINI TM, TOUYZ RM: NADPH oxidases, reactive oxygen species, and hypertension: clinical implications and therapeutic possibilities. Diabetes Care 31 (Suppl 2): S170-S180, 2008.

PEROU CM, JEFFERY SS, VAN DE RIJN M, REES CA, EISEN MB, ROSS DT, PERGAMENSCHIKOV A, WILLIAMS CF, ZHU SX, LEE JCF, LASHKARI D, SHALON D, BROWN PO, BOTSTEIN D: Distinctive gene expression patterns in human mammary epithelial cells and breast cancers. Proc Natl Acad Sci USA 96: 9212-9217, 1999.

RAJAGOPALAN S, KURZ S, MÜNZEL T, TARPEY M, FREEMAN BA, GRIENDLING KK, HARRISON DG: Angiotensin II-mediated hypertension in the rat increases vascular superoxide production via membrane NADH/NADPH oxidase activation. Contribution to alterations of vasomotor tone. J Clin Invest 97: 1916-1923, 1996.

RECKELHOFF JF, ZHANG H, SRIVASTAVA K, ROBERTS LJ, MORROW JD, ROMERO JC: Subpressor doses of angiotensin II increase plasma $\mathrm{F}_{2}$-isoprostanes in rats. Hypertension 35: 476-479, 2000.

SEALEY JE, LARAGH JH: The renin-angiotensin-aldosterone system for normal regulation of blood pressure and sodium and potassium homeostasis. In: Hypertension: Pathophysiology, Diagnosis and Management, $2^{\text {nd }}$ ed. Raven Press Ltd., New York, 1995, Chapter 105.

SIES H: Oxidative stress: oxidants and antioxidants. Exp Physiol 82: 291-295, 1997. 
SOMOVA L, KHAN MS, CHETTY S: Stress and salt intake: experimental data on Dahl saltresistant and saltsensitive rats. Stress Medicine 14: 125-134, 1998.

TANIYAMA Y, GRIENDLING KK: Reactive oxygen species in the vasculature: molecular and cellular mechanisms. Hypertension 42: 1075-1081, 2003.

TOUYZ RM: Reactive oxygen species in vascular biology: role in arterial hypertension. Expert Rev Cardiovasc Ther 1: 91-106, 2003.

TOUYZ RM: Reactive oxygen species, vascular oxidative stress and redox signaling in hypertension: What is the clinical significance? Hypertension 44: 248-252, 2004.

ZALBA G, BEAUMONT FJ, SAN JOSÉ G, FORTUŃO A, FORTUŃO MA, ETAYO JC, DIEZ J: Vascular $\mathrm{NADH} / \mathrm{NADPH}$ oxidase is involved in enhanced superoxide production in spontaneously hypertensive rats. Hypertension 35: 1055-1061, 2000. 